\title{
Morpho-physiological Adaptations and Histological Changes in Response to Phyllocnistis citrella Stainton
}

\author{
Anjitha George $^{1 *}$, S. Kuttalam ${ }^{2}$ and C.N. Rao ${ }^{1}$ \\ ${ }^{1}$ ICAR-Central Citrus Research Institute, Nagpur, Maharashtra 440 033, India \\ ${ }^{2}$ Tamil Nadu Agricultural University, Coimbatore -641 003, Tamil Nadu, India \\ *Corresponding author
}

\begin{tabular}{|c|c|}
\hline \multicolumn{2}{|r|}{ A B S T R A C T } \\
\hline & \multirow{6}{*}{$\begin{array}{l}\text { Evaluation of susceptibility or tolerance of selected major citrus cultivars towards citrus } \\
\text { leaf miner, Phyllocnistis citrella stainton (Lepidopters: Gracillaridae) based on innate } \\
\text { morphological or physiological attributes in the young expanding citrus leaves were } \\
\text { studied in the seedling stage as well as in pre-bearing orchards during spring and winter } \\
\text { flushing. Further, focussed on histochemical changes inside the leaf in response to citrus } \\
\text { leaf mining morphological parameters like leaf thickness, wax content and trichome } \\
\text { density; physiological changes in total phenol content in different leaf ages in the selected } \\
\text { cultivars. Citrus maxima Merr was found less susceptible to citrus leaf miner attack among } \\
\text { the seven cultivars and had dense trichomes, leaf thickness and higher leaf wax content. } \\
\text { Higher the total phenol content, lesser was the pest incidence. Results confirmed that due } \\
\text { to leaf mining, injury is caused only to epidermal layer which gets removed/peeled off } \\
\text { later exposing the mesophyll tissue. Results confined there is no significant histological } \\
\text { changes in the leaves due to mining. Hence, citrus leaf miner could be included under the } \\
\text { second category of non-gall forming type. }\end{array}$} \\
\hline Keywords & \\
\hline & \\
\hline $\begin{array}{l}\text { Histochemical, Host } \\
\text { plant resistance, } \\
\text { Susceptibility }\end{array}$ & \\
\hline Article Info & \\
\hline $\begin{array}{l}\text { Accepted: } \\
24 \text { Novem } \\
\text { Available } \\
10 \text { Decem }\end{array}$ & \\
\hline
\end{tabular}

\section{Introduction}

The microlepidopteran, Phyllocnistis citrella Stainton (Family: Gracillaridae), commonly known as citrus leaf miner (CLM) is an important pest of nurseries and young foliage of citrus. In India, more than $80 \%$ of the Citrus reticulata Blanco (Nagpur mandarin) nurseries are found severely affected by leaf miner especially in Central India (Shivankar $e t$ al., 2002); with infestation ranging from 7.40 to $87.00 \%$ on Citrus aurantifolia (Christm) Swingle and 1.00 to $55.90 \%$ in Citrus maxima Merr during peak flushing season (Alexander et al., 2015). Heavy infestation of P. citrella can severely damage young citrus trees in the field or in nurseries, while the damage is less significant in mature trees (Garcia-Marí et al., 2002).

In order to combat the insect pest damage and for qualitative and quantitative increase of yield, sustainable approaches for insect pest management are very much essential. The spray timings are the most important in managing leaf miner before entering in leaf tissue and it is highly susceptible to the toxic effect of pesticides (Pradhan, 1969). 
Therefore, it is essential to develop alternative management strategies for leaf miner which includes components like host plant resistance, biological control, sex pheromones, botanicals and bio-rationales apart from synthetic insecticides.

Host plant resistance (HPR) to insects is an effective, economical, and environment friendly method of pest control. Ovipositional preference was considered to be an important factor in deciding the suitability of a species or variety to $P$. citrella (Goane et al., 2008). Till date, very little is known about plant resistance to CLM.

Leaf trichome density is considered a mechanism of defence in plants to prevent or diminish damage by herbivores (Levin, 1973; Johnson, 1975; Rodriguez et al., 1984; Juniper and Southwood, 1986; Marquis, 1992). There seems to be difference in the susceptibility of citrus cultivars to the pest, with grapefruits and tangerines appearing the most susceptible (Argov and Rossler, 1996). Differential susceptibility among varieties has been found in India (Batra and Sandhu, 1983), Australia (Wilson, 1991), Spain (Jacas et al., 1997) and elsewhere (Heppner, 1993).

In some of these studies, the existence of antibiotic mechanisms of resistance was also indicated (Batra and Sandhu, 1983; Batra et al., 1984; Jacas et al., 1997), while in others, a plant phenology leading to $P$. citrella avoidance was described (Singh et al., 1988; Padmanaban, 1994; Jacas et al., 1997). Certain morphological parameters like leaf thickness which is an important criteria for CLM attack (Fahim, 2001; Alexander et al., 2015) has been already reported. Hence the present study was undertaken to understand the existence of any citrus leaf attributes, secondary metabolites, histological changes in the leaves in response to leaf mining in seven citrus cultivars.

\section{Materials and Methods}

\section{Leaf thickness}

For the measurement of leaf thickness in three age groups viz., feather leaf, 15 and 30 days old fresh leaves were collected from tagged plants of two citrus rootstocks, viz Citrus jambhiri Lush. and Citrus limonia Osbeck in nursery; grownup orchards of 5 - 6 years old trees (6 m x $6 \mathrm{~m}$ spacing) of Citrus reticulata Blanco, Citrus aurantifolia Swingle, Citrus sinensis (L.), Citrus maxima Merr. and Kinnow mandarin \{['King' (Citrus nobilis Lour.) $\times$ 'Willow Leaf' (Citrus deliciosa Ten.)]\}. Ten leaves from three different age groups per cultivar were collected in separate brown paper bags $\left(20 \times 10 \mathrm{~cm}^{2}\right)$, and leaf sections were made with fine blade. Using Leica MZ 205 A stereozoom microscope, the thickness of the sections were measured from leaf margin till midrib portion (thickness of midrib was excluded) and average thickness was expressed in millimetres ( $\mathrm{mm})$.

\section{Trichome density}

The presence and number of trichomes per $\mathrm{mm}^{2}$ area of abaxial surface of leaf (10 leaves/age) were studied in each citrus cultivars to establish correlation if any with susceptibility of species to CLM attack using Leica MZ 205 A stereozoom microscope.

\section{Wax estimation}

The method described by Woodhead and Padgham (1998) was followed for the estimation of surface lipids in the leaves of each citrus cultivars from 15, 30 and 45 days old freshly collected leaves from already tagged trees/seedlings. The leaves were weighed and immersed separately in $20 \mathrm{ml}$ of chloroform for 24 hours under dark conditions. The resultant whitish wax flakes were weighed and stored at $-20{ }^{0} \mathrm{C}$. Wax content per $g$ leaf was expressed. 


\section{Total phenol content}

$0.5 \mathrm{~g}$ of the leaf sample was taken and ground it with pestle and mortar in 10-time volume of $80 \%$ ethanol. Centrifuged the homogenate at $10,000 \mathrm{rpm}$ for 20 minutes supernatant. Reextracted the residue with 5 times the volume of $80 \%$ ethanol centrifuged and pooled the supernatants. Evaporated the supernatant to dryness and dissolved the residue in known (5 $\mathrm{ml}$ ) volume of distilled water. Pipetted different aliquots $(0.2$ to $2 \mathrm{ml})$ in to test tubes and made the volume in each tube to $3 \mathrm{ml}$ with water. Then, added $0.5 \mathrm{ml}$ of Folin-ciocalteu reagent and $2 \mathrm{ml}$ of $\mathrm{Na}_{2} \mathrm{CO}_{3}$ solution to each tube after 3 minutes. After mixing, placed the tubes in boiling water exactly for one minute, cooled and measured the absorbance at 650 $\mathrm{nm}$ against a reagent blank. Prepared standard curve using different concentration of gallic acid and the content of phenolics in extracts was expressed as gallic acid equivalent $(\mathrm{mg} / 100 \mathrm{ml})$.

\section{Histochemistry}

Leaf cross sections of mined C.aurantifolia and C.maxima cultivars were collected based on initial injury, callus thickening, regreened areas etc. Collected leaves were fixed in Formalin - Acetic Acid - Alcohol (FAA: $5 \mathrm{ml}$ Formalin $+5 \mathrm{ml}$ Acetic Acid $+70 \%$ Ethanol $9 \mathrm{ml}$ ) and leaf sections were prepared at Plant Anatomy Research Institute, Tambaram, Chennai, Tamil Nadu, India. The sections were stained by using a combination of stains (safranin and fast green) for getting anatomical characters of tissue sections. To supplement further, leaf miner damaged leaf sections of C.aurantifolia and C.maxima cultivars were examined under scanning electron microscope (SEM without EDAX by FEI-Quanta 250) at Tamil Nadu Agricultural University, Coimbatore, Tamil Nadu for any salient anatomical features. Leaves were cut in $\sim 1 \mathrm{~cm}^{2}$ squares from near the middle of injured leaves and sections of $10 \mu \mathrm{m}$ thick were made on a rotary microtome and mounted with double-sided adhesive tape attached to aluminum stubs. The stubs were sputter coated with a thin layer of Gold/Palladium (80: FEI, Quanta 250/20\%) and the coated specimens were examined at different magnifications.

\section{Results and Discussion}

Morphological parameters like leaf thickness, trichome density and wax content were assessed in different age groups citrus species under study. Leaf thickness (distance between upper and lower epidermis) showed an increasing trend with the age of the leaves up to 15 days of leaf expansion irrespective of the citrus species under study. In C.maxima, leaf thickness was significantly high i.e. 0.146 and $0.275 \mathrm{~mm}$ (mean) in feather leaf and 15 day old leaf while it was the lowest in C.jambhiri and C.aurantifolia cultivar with an average thickness of 0.109 and $0.117 \mathrm{~mm}$, respectively in feather leaf stage. The same trend was observed in 15 days old leaf with 0.136 and $0.122 \mathrm{~mm}$ in C.aurantifolia and C.jambhiri cultivar, respectively. A declining trend in leaf thickness was observed in 30 day old leaves with $0.090 \mathrm{~mm}$ in C.maxima and $0.076 \mathrm{~mm}$ in C.sinensis which was the maximum thickness among the seven citrus species studied (Table $1)$.

Trichomes were found on the abaxial surface as well as on the midrib of the leaves in all the cultivars in varying intensities except kinnow mandarin. Number of trichomes in feather flush varied from 1-2 per $\mathrm{mm}^{2}$ in C.jambhiri, C.limonia, C.reticulata, C.aurantifolia and C.sinensis cultivars distribution of hairs along and on the midribs while sparse on the lamina portion. In just emerged leaves of C.maxima, the number of trichomes varied from 25-37 hairs with average trichome density of $31.5 \pm$ 6.89 per $\mathrm{mm}^{2}$ area (mean \pm SD) (Fig. 1 and 2). 
While, C.aurantifolia had sparse distribution of trichomes with $1.25 \pm 0.96$ per $\mathrm{mm}^{2}$ (t-test significant at $P \leq 0.05$ ) (Fig. 3 and 4). Density of hairs was more along the midrib in C.maxima species which is the most preferred site for egg laying by CLM moths on lower leaf surface.

Wax content in 15 day old leaf was observed only in C.maxima cultivar with a mean wax content of $12.56 \mu \mathrm{g} / \mathrm{g}$. While it might be absent or in traces in the rest of the cultivars as it was undetectable. As the age of the leaf increased, the wax content declined to 8.66 and $2.57 \mu \mathrm{g} / \mathrm{g}$ in 30 and 45 day old leaves, respectively.

Total phenol content was significantly high in 15 days old healthy kinnow leaves with $142.45 \mathrm{mg} / 100 \mathrm{ml}$ followed by C.reticulata (130.73 mg/100 ml). In citrus leaf miner infested 15 days old leaves, C.maxima recorded total phenol content of 177.92 $\mathrm{mg} / 100 \mathrm{ml}$. In 30 days old healthy leaves, C.reticulata had a phenol content of 167.90 $\mathrm{mg} / 100 \mathrm{ml}$ followed by kinnow with 157.13 $\mathrm{mg} / 100 \mathrm{ml}$ while in infested C.reticulata (156.92) and kinnow (164.31) followed by C.aurantifolia (143.54) significantly recorded higher phenol content (mg/100 ml) (Fig. 5). More the total phenol content, lesser the susceptibility to CLM attack.

Cross sections of the leaf lamina of C.aurantifolia (most susceptible to CLM) and C.maxima (least susceptible) showed that the citrus leaf miner larva hollows a tunnel into the epidermal layer, not damaging the other leaf tissues. The larva immediately after hatching burrows into the epidermal cell layer of the leaf forming galleries and exposes leaf mesophyll. It infested the adaxial part of the midrib as well as the lateral part of the midrib (Fig. 6a,b). The larvae chewed the leaf tissue and made wide circular (cylindrical) chamber through which it feeds. Leaf crumpling as a result of leaf mining was induced by damage to the cuticular layer. There was no active response of plant tissue to the pest but with a layer of mesophyll tissue seen enclosing the chamber. In C.aurantifolia, there was a crushed tissue all around the insect chamber. The diameter of the insect chamber in C.aurantifolia leaves ranged from 80-110 $\mu \mathrm{m}$. In C.maxima, the insect chamber was located within any region of the lamina viz., adaxial part, submarginal part of the midrib and abaxial part (Fig. 7a,b). The cavity diameter in C.maxima was more than that of C.aurantifolia with a mean diameter of $120 \mu \mathrm{m}$. Even though the leaf tissue adjacent to the insect chamber was crushed, but no changes either in cell size or shape was observed.

Host plants have some physical defense traits, such as trichomes on the leaves, stem etc. In citrus species also, the presence and number of trichomes on per $\mathrm{mm}^{2}$ area on the adaxial surface of the leaf and midrib which is the most preferred site for oviposition. C.aurantifolia species had shown maximum leaf miner infestation while it was least in C.maxima in our studies. Dense trichomes on C.maxima leaves might be one of the reason for low preference among the cultivars studied as hairs/trichomes impede oviposition while trichomes were very less in C.aurantifolia. As the age of the leaf was increased, the trichome density also got reduced and even absent in some of them.

On newly emerged leaves, in addition to higher densities, decrease in trichome density with leaf age has been documented by Yamawo et al., (2012). Several reports of plant species using trichomes on young new leaves to obstruct herbivore activity, not only because young growing leaves have high assimilative value and contain high concentrations of nutrients (Coley and Barone, 1996; van Dam et al., 1996; Heil, 2008; 
Lambdon and Hassall, 2005; Radhika et al., 2008) substantiate the present finding.

Leaf toughness could limit population buildup of certain pests (Kadapa et al., 1988). Thin leaf lamina could be one of the factors imparting susceptibility against sucking pests. Hardness of various plant tissues has been reported to be correlated with the resistance to insect pests. There was negative correlation between percent leaf miner infestation and leaf thickness in just emerged, 15 and 30 day old leaves $\left(\mathrm{R}^{2}=-0.78^{*},-0.69^{*}\right.$ and -0.24$)$. Toughness and thickness of various plant parts adversely affected penetration and feeding by insects Dhaliwal and Singh (2005) and Lakshminarayanan et al., (2008).

Cuticle is the barrier to insect-pests for piercing into the plant system. Lignin, latex and wax deposits on leaves are other mechanical defenses by the host plant to evade pest attack. It is accepted that citrus leaf and fruit cuticles carry a thin film of epicuticular waxes on the surface of their cutin matrix (Baker and Procopiou, 1975). Wax constituents act as allelochemicals by influencing fungal development (Carver et al., 1990) and or insect behavior (Stadler, 1986; van Loon et al., 1992). Leaf wax deposits ranging from $20 \mu \mathrm{g} / \mathrm{cm}^{2}$ in orange to 31 $\mu \mathrm{g} / \mathrm{cm}^{2}$ in lemon have been recorded to be consistent during all except the most juvenile stages of growth (Edward et al., 2006). Contrary to the above report, wax content was observed only in C.maxima in the study while in rest of citrus species, it would be in minute traces or was not detected. Wax content was highest in the early stage in C.maxima leaves and this internal hardness of leaf tissue could be an obstacle to feeding by CLM larva (Edwards and Wratten, 1982) as reported in case of aphids.

Total phenol content was estimated in three different ages (from tagged branches) viz., 15,
30 and 45 day old leaves of C.jambhiri, C.limonia, C.aurantifolia, C.reticulata, C.sinensis, C.maxima and kinnow. Total phenol content was maximum in the initial period i.e. in 15 day old leaves than 30 and 45 days old leaves. Leaf miner infested leaves had more phenol content than healthy leaves (t-test significant at 5\%). In citrus leaf miner infested leaves, C.maxima had the highest total phenol content of $177.92 \mathrm{mg} / 100 \mathrm{ml}$ followed by $137.41 \mathrm{mg} / 100 \mathrm{ml}$ in C.jambhiri in 15 day old leaves while C.reticulata (156.92) and kinnow (164.31) followed by C.aurantifolia (143.54) significantly recorded higher phenol content in 30 day old leaves. Leaf mining might be an inducing factor for the initiation of secondary metabolite production in citrus leaves leading to high phenol production especially in younger leaves as seen from the values. Damage to the epidermis caused by the mining activity of Phyllocnistis populiella Chambers led to the induction of phenolic glycosides in aspen leaf tissue than insecticide treated leaves (Young et al., 2010). In particular, the properties of tannins and total phenols in leaf tissue have been widely reported as an index of plant chemical defense in eucalyptus leaves (Macauley and Fox, 1980). Sahoo and Patnaik (2003) observed a negative correlation between total phenolic content and pod borer damage. Our studies also showed total phenol concentration as a leading and reliable indicator of resistance against CLM.

Phenol content decreased as the age of the leaf increased in the study. Several studies of fastgrowing plants also demonstrated that chemical substances decrease with leaf age (McKey, 1974) as a result of the reallocation of the substances from maturing leaves to new leaves (van Dam et al., 1994). The phenolic compounds of citrus are secondary metabolic products that are believed to be produced as a result of the plant's interaction with the environment (Beier and Oertli, 1983; Zaat et 
al., 1987; Laks and Pruner, 1989). The experimental results indicated that increase in total phenols is considered elements of induced resistance in hosts against herbivory.

Cross sections of the leaf lamina of mined C.aurantifolia (maximum leaf miner infestation) and C.maxima (minimum leaf miner infestation) were examined. The leaf mine originated near the midvein on the lower surface of the leaf where the eggs are usually laid. Photosynthetic tissues were found below in the mesophyll cell. Due to the leaf miner attack, some leaf blades appeared to be crumpled while in some the necrotic tissues (cuticular layer) were blown away in the wind (Fig. 8). The compact cells in C.maxima could serve as physical barrier for mining due to increased toughness of the leaf tissue.

Table.1 Leaf thickness of citrus species at different stages of crop growth

\begin{tabular}{|l|c|c|c|}
\hline \multirow{2}{*}{ Citrus Cultivars } & \multicolumn{3}{|c|}{ Leaf thickness (mm) } \\
\cline { 2 - 4 } & Just emerged & 15 day old & 30 day old \\
\hline C.jambhiri & $0.109 \pm 0.005$ & $0.122 \pm 0.002$ & $0.042 \pm 0.02$ \\
\hline C.limonia & $0.127 \pm 0.004$ & $0.171 \pm 0.003$ & $0.072 \pm 0.02$ \\
\hline C.aurantifolia & $0.117 \pm 0.001$ & $0.136 \pm 0.003$ & $0.069 \pm 0.03$ \\
\hline C.reticulata & $0.128 \pm 0.003$ & $0.181 \pm 0.001$ & $0.039 \pm 0.02$ \\
\hline C.sinensis & $0.142 \pm 0.004$ & $0.191 \pm 0.004$ & $0.076 \pm 0.01$ \\
\hline C.maxima & $0.146 \pm 0.008$ & $0.275 \pm 0.005$ & $0.090 \pm 0.04$ \\
\hline Kinnow & $0.139 \pm 0.006$ & $0.157 \pm 0.004$ & $0.063 \pm 0.01$ \\
\hline
\end{tabular}

Fig.1 Trichomes on bud burst and feather flush of C.maxima
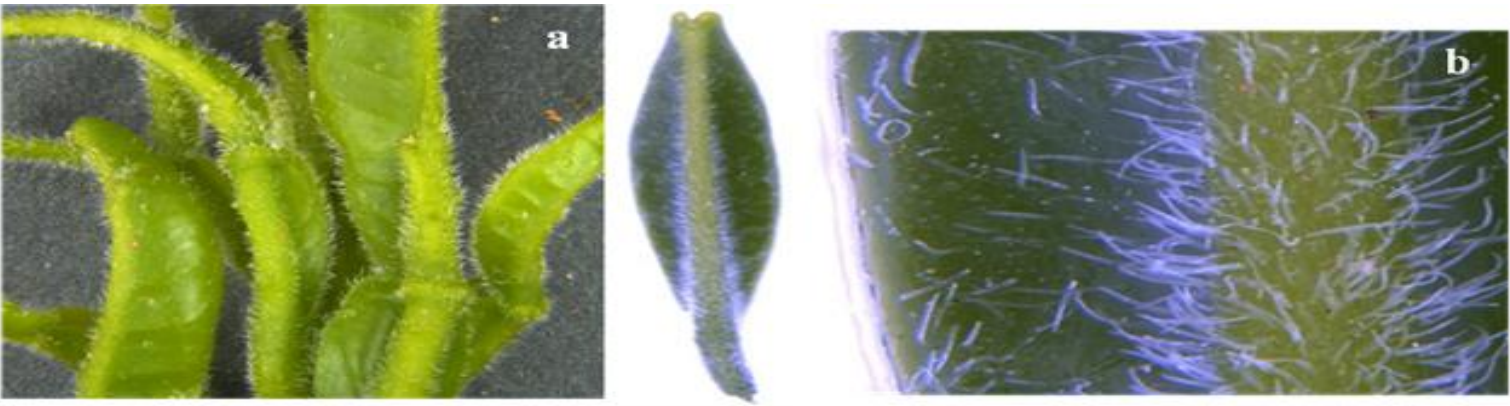

Fig.2 Scanning electron micrograph of dense trichomes in feather flush of C.maxima

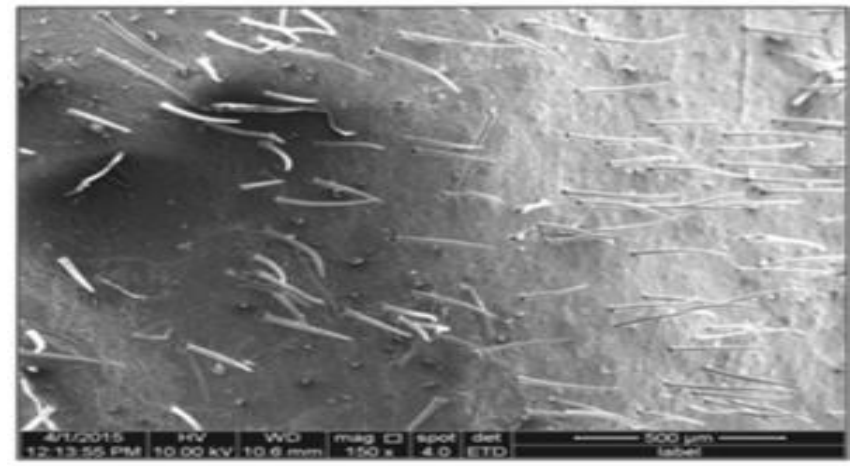


Fig.3 Sparse trichomes on bud burst and feather flush of C.aurantifolia
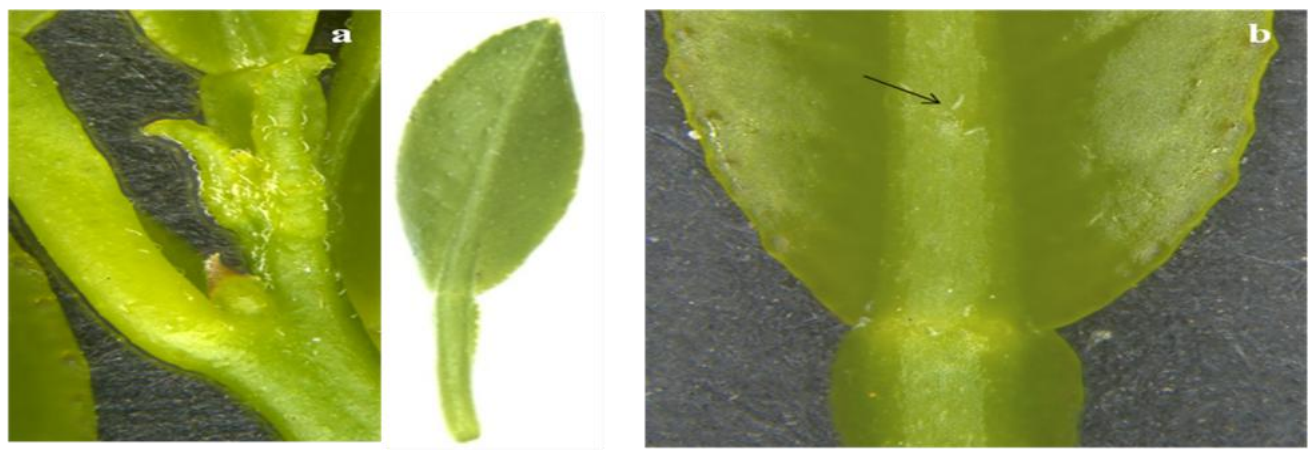

Fig.4 Scanning electron micrograph of sparse trichomes in feather flush of C.aurantifolia

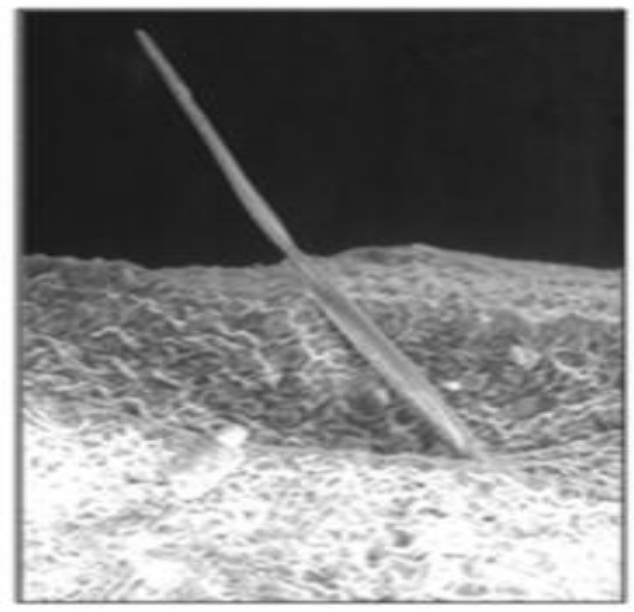

Fig.5 Total phenol content $(\mathrm{mg} / 100 \mathrm{ml})$ in mined and non-mined leaves of citrus cultivars

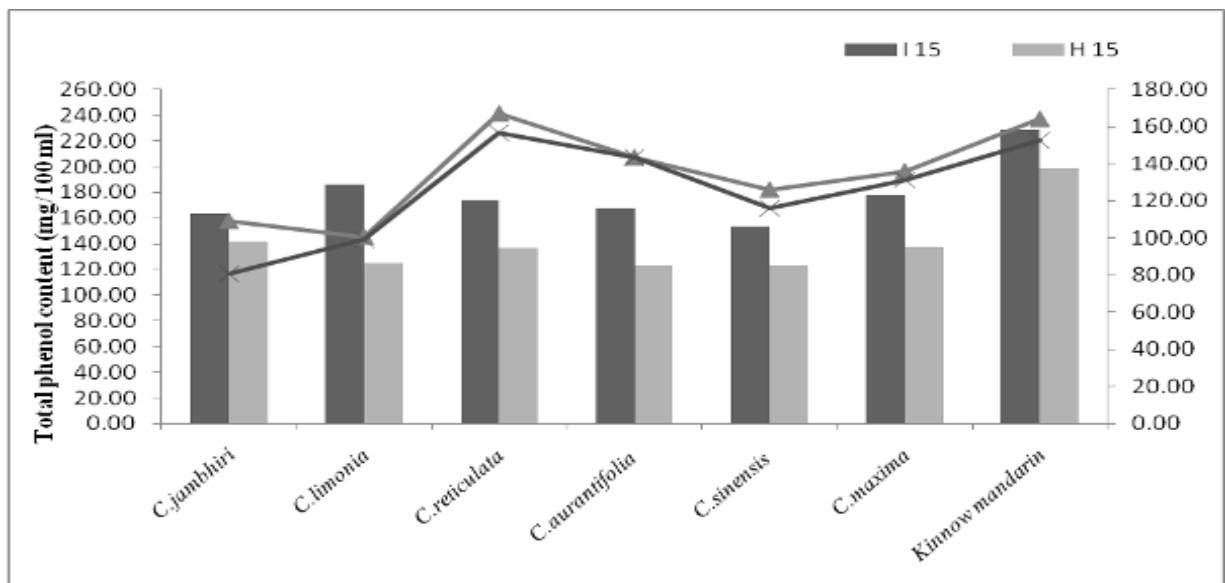

*I- Infested; H- Healthy

Values followed by same letter in a column are not significantly different $(\mathrm{P}=0.05)$ 
Fig.6a Transverse section of leaf through midrib of acid lime showing CLM larval Chamber

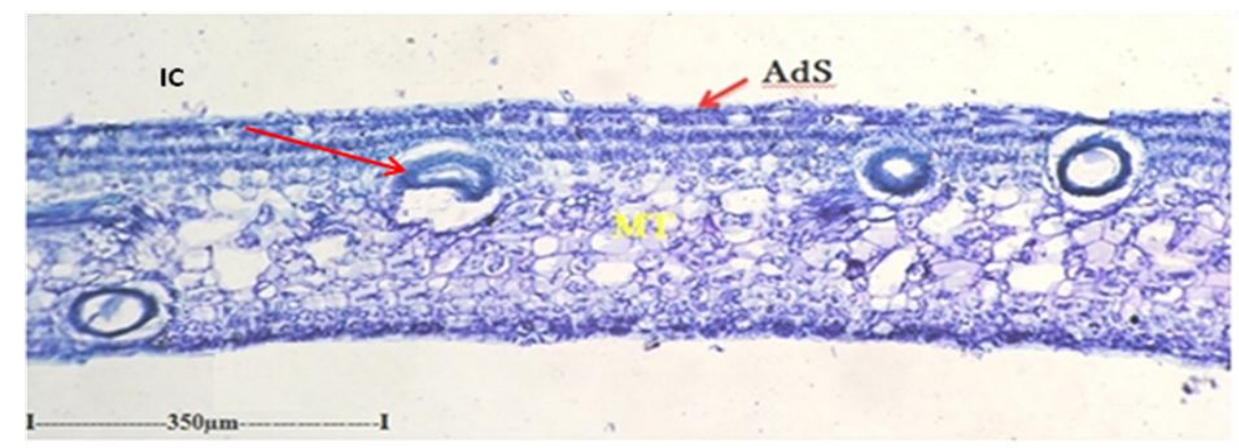

AdS-Adaxial side; IC-Insect Cavity; In-Insect; MT-Mesophyll Tissue

Fig.6b Transverse section of leaf lamina showing CLM larval chamber in C.aurantifolia

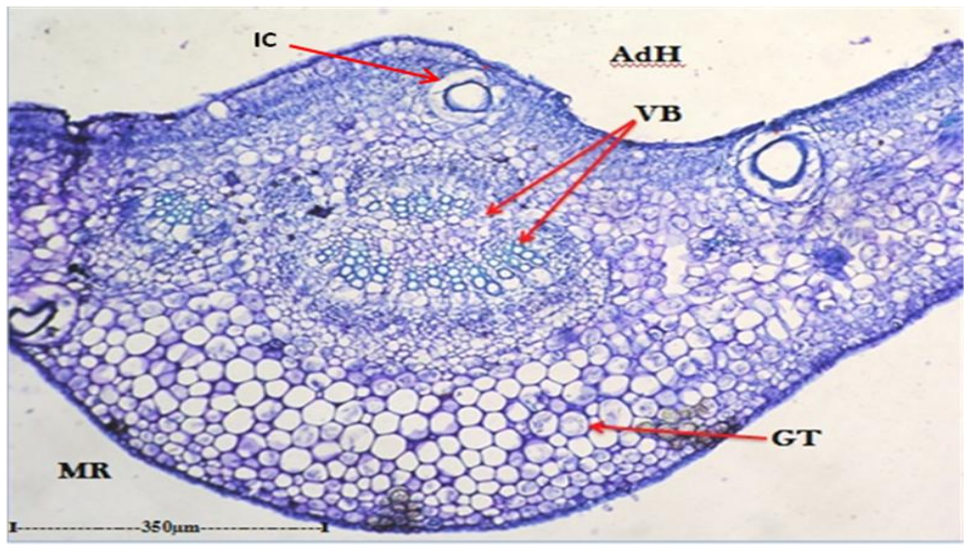

AdH-Adaxial Lump of the midrib; GT- Ground parenchyma Tissue; IC-Insect Cavity; InInsect; MR-Midrib; VB- Vascular Bundles

Fig.7a CLM larva located in the sub-epidermal layer of the adaxial surface of lamina in maxima

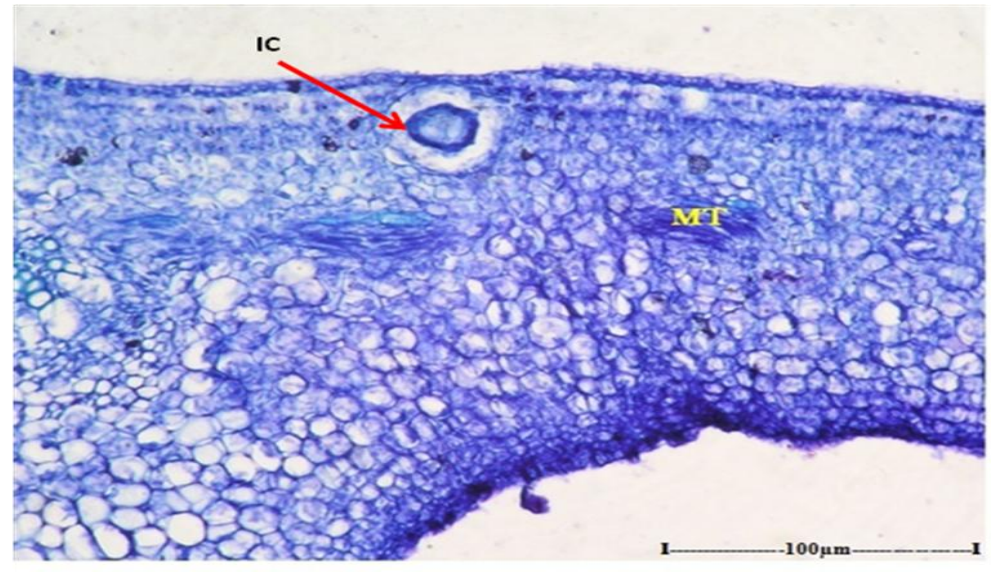

IC- Insect Cavity; MT- Mesophyll Tissue 
Fig. 7b CLM larva located on the sub-marginal layer of the lamina in C.maxima

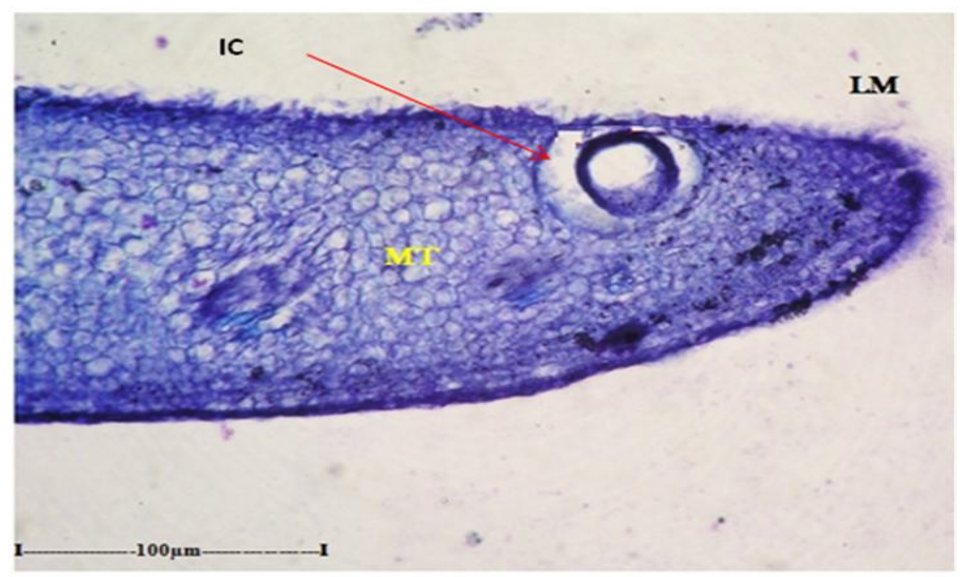

IC- Insect Cavity; In- Insect; LM- Leaf Margin; MT- Mesophyll Tissue

Fig.8 Tunnel excavated by CLM larva in C. aurantifolia feather flush followed by loss of cuticular layer
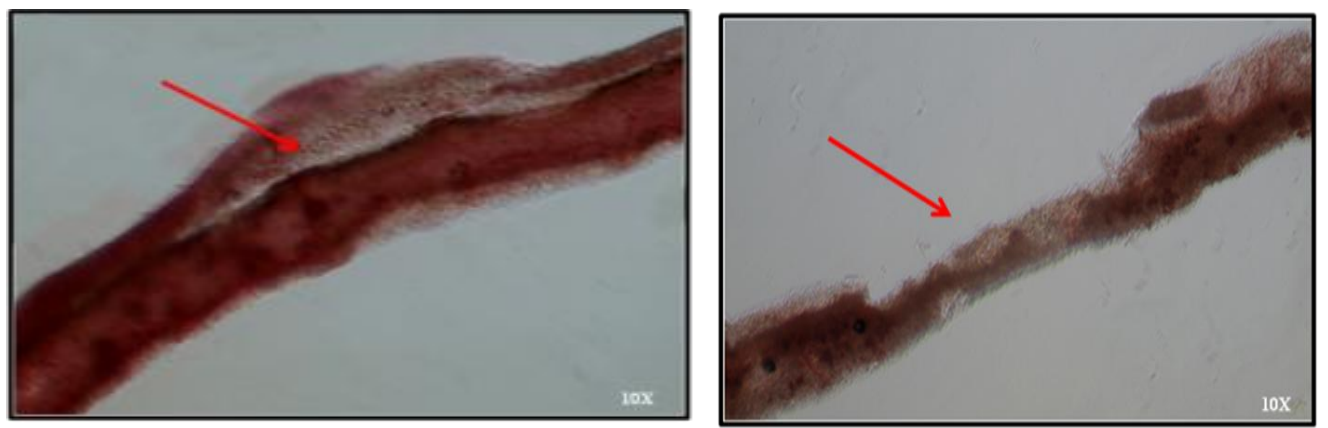

Fig.9 Scanning electron micrograph of swollen callus cells formed over injured portion

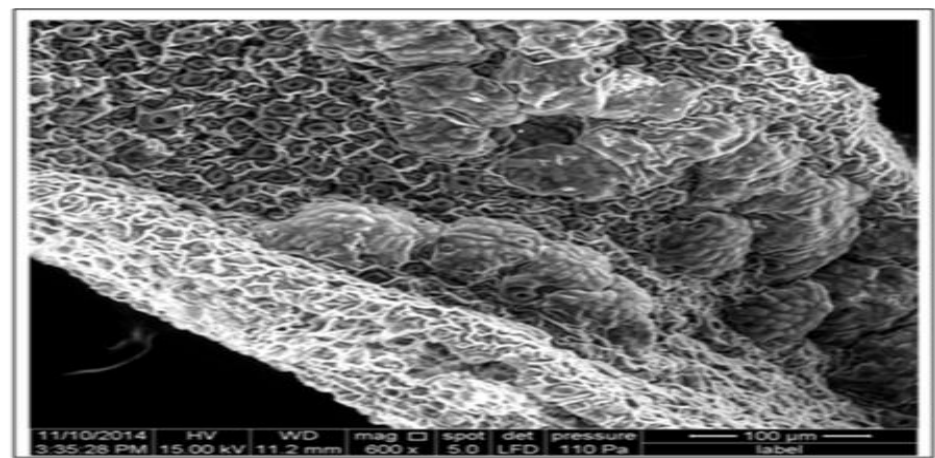

The insect larva chewed the leaf tissue and made wide circular (cylindrical) chamber through which the insect was feeding. The saliva secreted by the larva during tunneling does not seem to be cecidogenic. In some of the sections where regreening had occurred, new and thin epidermal layer was formed. The epidermal surface was not plane but with bulbous callus cells (Fig. 9). In older leaves where the mine cover was absent, a wound 
periderm developed with multilayered cells. Hering (1951) reported that the most common plant reaction to mine formation was the development of callus tissue. The cells of this tissue are typically large and turgid with thin cell walls. Callus development is often associated with injury to young than mature tissue.

Among the phytophagous insects, there are two categories viz., those which induce hypertrophy and hyperplasia leading to formation of galls of different morphological type and those which simply feed externally or mine the leaf/stem and form cavities inside the plant organs. In the non-gall forming types, there is no significant histological changes in the host plant. Hence, citrus leaf miner could be included under the second category of non-gall forming type. Understanding the consequences due to citrus leaf miner mining is highly essential as it indirectly helps citrus canker infection.

\section{Acknowledgments}

We acknowledge Director, ICAR- Central Citrus Research Institute, Nagpur for the facilities provided for conducting the experiments.

\section{References}

Alexander, A., Kuttalam, S. and Rao, C.N. 2015. Interaction of certain leaf parameters and weather on incidence of citrus leaf miner, Phyllocnistis citrella Stainton on major citrus cultivars. Journal of insect science 28(1):223-229.

Argov, Y. and Rossler, Y. 1996. Introduction, release and recovery of several exotic natural enemies for biological control of the citrus leaf miner, Phyllocnistis citrella, in Israel. Phytoparasitica 24: 33-38.
Baker, E.A. and Procopiou, J. 1975. The cuticles of Citrus species. Composition of the intracuticular lipids of leaves and fruits. Journal of the Science of Food and Agriculture 26:1347-1352.

Batra, R.C., Baja, K.L. and Sandhu, G.S. 1984. Phenolic content in relation to incidence of citrus leaf miner in citrus germplasm. Journal of Research, Punjab Agriculture University 21:203-206.

Batra, R.C. and Sandhu, G.S. 1983. Mechanism of resistance in Troyer citrange to citrus leaf miner. Journal of Research, Punjab Agriculture University 20(4):558-559.

Beier, R.C. and Oertli, E.H. 1983. Psoralen and other linear furocoumarins as phytoalexins in celery. Phytochemistry 22:2595-2597.

Carver, T.L.W., Thomas, B.J. Ingersonmorris, S.M. and Roderick, H.W. 1990. The role of the abaxial leaf surface waxes of Lolium spp. in resistance to Erysiphe graminis. Plant Pathology 39:573-583.

Choong, M.F. 1996. What makes a leaf tough and how this affects the pattern of Castanopsis fissa leaf consumption by caterpillars. Functional Ecology 10: 668-674.

Coley, P.D. and Barone, J.A. (1996). Herbivory and plant defenses in tropical forests. Annual Review of Ecology and Systematics 27:305-335.

Dhaliwal, G.S. and Singh, R. 2005. In: (Eds.) G.S. Dhaliwal and Ram Singh, Host Plant Resistance to Insects: Concepts and Applications. Panima Pub. Corp., New Delhi, p: 578

Edward, A.B., Procopiou, J. Hunt, G.M. 2006. The cuticles of citrus species. Composition of leaf and fruit waxes. Journal of the Science of Food and Agriculture 26(8):1093-110. 
Fahim, S.M.E.M. 2001. Biological and ecological studies on the citrus leafminer Phyllocnistis citrella Staint. M.Sc. Thesis, Department of Plant Protection Cairo University of Egypt. 235p.

Garcia, Mari, F., Granda, C. Zaragoza, S. and Agusti M. 2002. Impact of citrus leafminer (Lepidoptera, Gracillariidae) on leaf area development and yield of mature citrus trees in the Mediterranean area. Journal of Economic Entomology 95: 966-974.

Goane, L., Valladares, G. and Willink, E. 2008. Preference and performance of Phyllocnistis citrella Stainton (Lepidoptera: Gracillariidae) on three citrus hosts: laboratory and field assessment. Environmental Entomology 37(4):1025-1034.

Heil, M. 2008. Indirect defence via tritrophic interactions. New Phytologist 178, 41-61.

Heppner, J.B. 1993. Citrus leafminer, Phyllocnistis citrella, in Florida. Tropical Lepidoptera, 41:49-64.

Hering, E.M. 1951. The biology of the leaf miners. Uitgeveverij Dr W. Junk, Gravenhage, Netherlands. 420 p.

Jacas, J.A., Garrido, A. Margaix, C. Forner, J. Alcaide, A. and Pina, J. 1997. Screening of different citrus rootstocks and citrus-related species for resistance to Phyllocnistis citrella (Lepidoptera: Gracillariidae). Crop Protection 16:701-705.

Kharbangar, M., Sudhanya, R.H. and Choudhury, S. 2015. Total phenol content in thrips infested rice leaves of Khasi Hills. Entomology and Applied Science Letters 2(1):42-46.

Laks, P.E. and Pruner, M.S. 1989. Flavonoid biocides: structure/activity relations of flavonoid phytoalexin analogues. Phytochemistry 28:87-91.

Lakshminarayanan, S., Singh, P.S, and
Mishra, D.S. 2008. Relationship between whitefly population, YMV disease and morphological parameters of green gram germplasm. Environment and Ecology 26(3): 978982.

Lambdon, P.W. and Hassall, M. 2005. How should toxic secondary metabolites be distributed between the leaves of a fast-growing plant to minimize the impact of herbivory. Functional Ecology 19:299-305.

Macauley, B.J. and Fox, L. 1980. Variation in total phenols and condensed tannins in Eucalyptus leaf phenology and insect grazing. Australian Journal of Ecology 5:31-35.

McKey, D. 1974. The distribution of secondary compounds within plants. In: (Rosenthal, G.A. and D.H. Janzen, eds). Herbivores: their interactions with secondary plant metabolites. New York, USA: Academic Press: $56-133$.

Padmanaban, B. 1994. Screening of citrus germplasm for controlling citrus leafminer (Phyllocnistis citrella) (Lepidoptera: Phyllocnistidae). Indian Journal of Agricultural Science 64:723-726.

Peeters, P.J. 2002. Correlations between leaf constituent levels and the densities of herbivorous insect guilds in an Australian forest. Austral Ecology 27: 658-671.

Pradhan, S. 1969. Pests of fruits and fruits trees. In: Insect pests of Crops. National Book Trust, New Delhi.

Radhika, V., Kost, C. Bartram, S. Heil, M. and Boland, W. (2008). Testing the optimal defence hypothesis for two indirect defences: extrafloral nectar and volatile organic compounds. Planta 228: 449-457.

Sahoo, B.K. and Patnaik, H.P. 2003. Effect of biochemicals on the incidence of 
pigeonpea pod borers. Indian Journal of Plant Protection 31:105-108.

Shivankar, V.J., Rao, C.N. and Singh, S. 2002. Citrus insect pest management. Manual No.1. National Research Centre for Citrus, Nagpur. p.11.

Singh, S.P., Rao N.S. Kumar, K.K. and Bhumannavar, B.S. 1988. Field screening of citrus germplasm against the citrus leaf miner, Phyllocnistis citrella Stainton. Indian Journal of Entomology 50(1): 67-75.

Singleton, V.L., Orthofer, R. and LamuelaRaventos, R.M. 1999. Analysis of total phenols and other oxidation substrates and antioxidants by means of Folin-Ciocalteu reagent. Methods Enzymology 299: 152-178.

Stadler, E. 1986. Oviposition and feeding stimuli in leaf surface waxes. In: (Juniper, B.E., T.R.E. Southwood, ed.s) Insects and the Plant Surface. Edward Arnorld, London. pp. 105121.

Van Dam, N.M., de Jong T.J. and Iwasa, Y. Kubo, T. 1996. Optimal distribution of defences: are plants smart investors. Functional Ecology 10: 128-136.

Van Dam, NM., Verpoorte, R. and van der Meijden, E. 1994. Extreme differences in pyrrolizidine alkaloid levels between leaves of Cynoglossum officinale. Phytochemistry 37:10131016.

Van Loon, J.J.A., Blaakmeer, A. Griepink,
F.C. van Beek, T.A. Schoonhoven, L.M. and de Groot, A. 1992. Leaf surface compound from Brassica oleracea (Cruciferae) induces oviposition by Pieris brassicae (Lepidoptera: Pieridae).

Chemoecology 3:39-44.

Wilson, C. 1991. Citrus leaf miner. Agnote Farwin No. 443-2 p.

Woodhead, S. and Padgham, D.E. 1998. The effect of plant surface characteristics on resistance of rice to the brown plant hopper, Nilaparvata lugens. Entomologia Experimentalis et Applicata 7:15-22.

Yamaw, A., Suzuki, N. Tagawa, J. and Hada, Y. 2012. Leaf ageing promotes the shift in defence tactics in Mallotus japonicus from direct to indirect defence. Journal of Ecology, Pp. 802809.

Young, B., Diane, W. Patricia, D. and Thomas, C. 2010. Induction of Phenolic Glycosides by Quaking Aspen (Populus tremuloides) Leaves in Relation to Extrafloral Nectaries and Epidermal Leaf Mining. Journal of Chemical Ecology 36:369-377.

Zaat, S.A.J., Van Brussel, A.A.N. and Tak, T. 1987. Flavonoids induce Rhizobium leguminosarum to produce nod DABC gene-related factors that cause thick, short roots and root hair responses on common vetch. Journal of Bacteriology, 169: 3388-3391.

\section{How to cite this article:}

Anjitha George, S. Kuttalam and Rao, C.N. 2018. Morpho-physiological Adaptations and Histological Changes in Response to Phyllocnistis citrella Stainton. Int.J.Curr.Microbiol.App.Sci. 7(12): 3578-3589. doi: https://doi.org/10.20546/ijcmas.2018.712.405 